\title{
SISTEM INFORMASI LOGISTIK STOCK OPNAME MENGGUNAKAN QUICK RESPONSE CODE BERBASIS ANDROID
}

\author{
Ipan A'shary Wulung, Ekojono, ST.,M.Kom, Atiqah Nurul Asri, SPd., MPd \\ Program Studi Teknik Informatika, Jurusan Teknik Elektro, Politeknik Negeri Malang \\ ipanasha@gmail.com
}

\begin{abstract}
Abstrak
Sistem Informasi Logistik Stock Opname memberikan informasi mengenai barang yang terdapat di gudang antara lain jumlah tiap barang dan detail barang berupa merk dan nomor seri barang. Informasi tersebut ditampilkan secara mobile melalui aplikasi yang berbasis sistem operasi Android. Bagian utama proses logistik yang berpengaruh besar pada perusahaan yang menerapkannya adalah stock opname. Stock opname adalah proses menghitung jumlah barang yang ada di gudang dan mencocokkannya dengan catatan pembukuan persediaan. Proses tersebut dipermudah dengan menggunakan QR (Quick Response) Code yang diaplikasikan kedalam sistem operasi Android sehingga proses stock opname tidak lagi dilakukan secara manual. Dalam system ini juga terdapat tampilan web untuk admin yang berguna untuk menampilkan dan mengolah semua data barang termasuk hasil stock opname yang sudah dilakukan. Selain itu, juga disediakan fitur search dan filter data untuk memudahkan pencarian barang dan fitur untuk mencetak laporan dari data tersebut. Terdapat fitur transaksi masuk dan transaksi keluar sebagai proses untuk melakukan pembelian barang dari supplier dan penjualan barang kepada bengkel yang membutuhkan.
\end{abstract}

Kata kunci: sistem informasi, quick response code, stock opname, android.

\section{Pendahuluan}

Kehidupan sebuah perusahaan sangat bergantung pada logistik dan pergudangan. Mengingat perannya yang sangat penting, kontrol yang tepat pada logistik akan memberikan peningkatan produktivitas dan pelayanan terhadap pergudangan yang akan mempengaruhi pada performa perusahaan secara keseluruhan.

Untuk menganalisa kinerja proses logistik, maka perlu dilaksanakan stock opname. Stock opname merupakan prosedur wajib dalam sistem logistik dan pergudangan untuk menganalisa apakah telah berjalan dengan efektif dan efisien kinerja proses logistik tersebut. Namun pada prakteknya, proses stock opname ini masih terbilang manual dengan mencatat satu persatu barang yang terdapat digudang. Hal tersebut tentunya akan memakan waktu dan diperlukan ketelitian yang tinggi agar data yang diambil tidak salah.

Pesatnya teknologi dan informasi saat ini didukung dengan berkembangnya sistem operasi pada smartphone karena beragam fitur dapat ditampilkan untuk memenuhi kebutuhan dan daya tarik tersendiri bagi penggunanya. Jenis-jenis sistem operasi smartphone diantaranya adalah Android, Windows Mobile, Blackberry, , Symbian, Iphone dan sebagainya.
Sistem operasi Android merupakan salah satu sistem operasi yang belakangan ini berkembang dengan pesat. Terdapat keunggulan dari sistem operasi ini antara lain dapat diubah atau di modifikasi sesuai dengan keinginan penggunanya dan banyaknya aplikasi komputer yang sudah tersedia. Selain itu, Android mudah digunakan dan bisa didapatkan dengan harga terjangkau.

Saat ini, teknologi komunikasi dan informasi terdapat suatu perkembangan yang signifikan dalam penggunaan kode dua dimensi misalnya pdf147, Datamatrix, Maxicode, Bar Code dan QR (Quick Response) Code (Ariadi, 2011).

QR Code adalah simbol matriks yang terdiri dari sebuah untaian kotak persegi yang disusun dalam sebuah pola persegi yang lebih besar. Kotak persegi ini kemudian disebut sebagai modul. Luasnya pola persegi ini akan menentukan versi dari QR Code.

QR Code sangat banyak digunakan dalam kehidupan sehari-hari. QR Code cukup membantu para konsumen untuk mendapatkan informasi atas produk yang mereka konsumsi. Seperti halnya barcode, di balik kode matriks itu tersimpan data, yakni informasi kontak, alamat e-mail, URL, nomor telepon, nama perusahaan, geoposition, jadwal acara, dan teks (Hadi, 2009). QR Code mengandung informasi yang hanya bisa dibaca dengan sebuah decoder (pembaca $Q R$ Code) yang berupa perangkat mobile berbasis Android. 
gambar QR Code tersebut dalam membuat sistem informasi logistik dan proses stock opname. Sistem informasi logistik ini nantinya akan membantu dalam transaksi barang secara mobile, baik itu saat barang masuk maupun keluar. Sedangkan proses stock opname akan dipermudah dengan menggunakan QR Code.

Setiap barang-barang di gudang nantinya akan diberikan gambar QR Code yang sudah dibuat dan dibaca oleh perangkat mobile berbasis Android sebagai decoder (pembaca QR Code). Hasil stock opname tersebut akan langsung dibandingkan dengan data dalam catatan pembukuan yang diambil dari database server dan dipanggil ke perangkat mobile berbasis Android. Sehingga kedepannya dalam proses stock opname bisa lebih cepat lagi dan tidak manual. Mencermati hal tersebut maka penulis ingin membuat optimasi stock opname menggunakan QR Code berbasis Android.

\section{Metode}

\subsection{Metode Penelitian}

Berikut merupakan kerangka penelitian yang digunakan oleh penulis dalam aplikasi

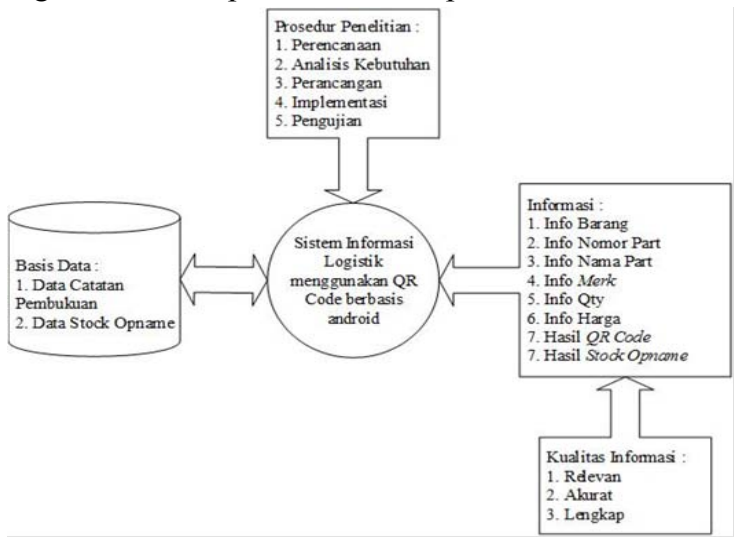

Gambar 2.1 Kerangka Konsep Penelitian

\subsection{Tahapan Penelitian}

Dalam tahap penelitian ini penulis akan menjelaskan tentang metode SDLC (Software Development Life Cycle) dengan model waterfall.

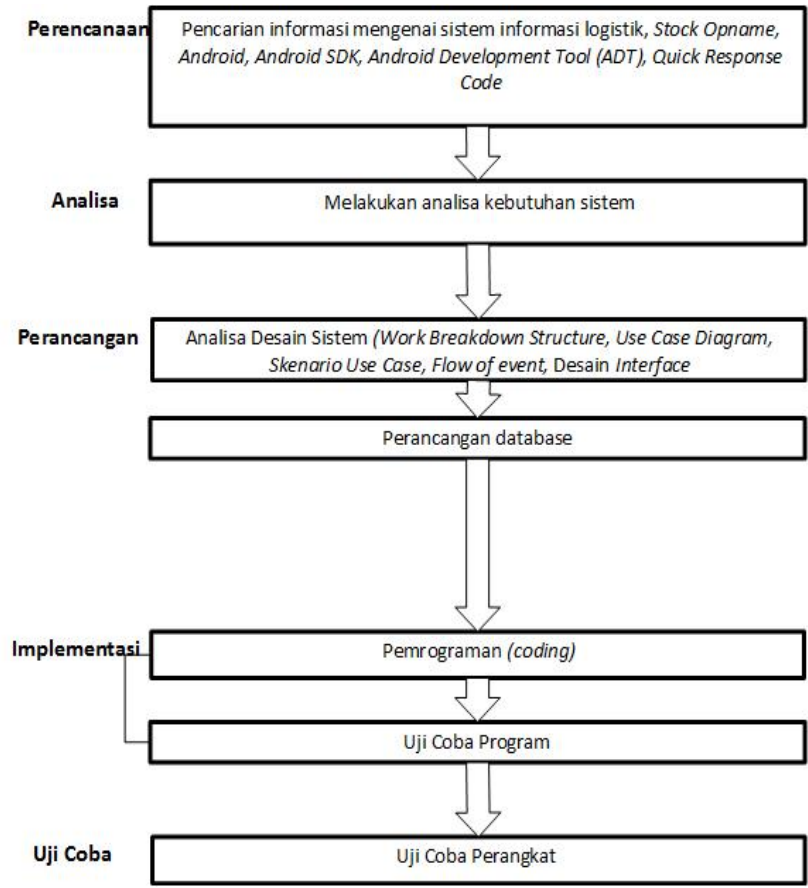

Gambar 2.2 Diagram Tahapan Penelitian

a. Perencanaan

Pada proses perencanaan, penulis mengumpulkan segala informasi terkait sistem yang akan dibangun, seperti Sistem Informasi Logistik, Stock Opname, Android, Android SDK, Android Development Tool (ADT), QR Code.

\section{b. Analisa Kebutuhan}

Langkah ini merupakan analisa terhadap kebutuhan sistem. Pengumpulan data dalam tahap ini bisa melakukan sebuah penelitian, wawancara atau studi literatur. Sistem analis akan menggali informasi sebanyak-banyaknya dari user sehingga akan tercipta sebuah konsep sistem Android yang bisa melakukan tugas-tugas yang diinginkan oleh user tersebut. Tahapan ini akan menghasilkan dokumen user requirment atau bisa dikatakan sebagai data yang berhubungan dengan keinginan user dalam pembuatan sistem. Dokumen ini lah yang akan menjadi acuan sistem analis untuk menerjemahkan ke dalam bahasa pemrogram.

\section{c. Perancangan Sistem}

Desain dan perancangan sistem merupakan pendefinisian dari kebutuhan-kebutuhan fungsional dan persiapan untuk rancang bangun implementasi. Desain sistem dapat didefinisikan sebagai penggambaran, perencanaan dan pembuatan sketsa atau pengaturan dari beberapa elemen yang terpisah ke dalam satu kesatuan yang utuh dan berfungsi, meliputi Work Breakdown Structure, Use Case Diagram, Skenario Use Case, Flow of event, Desain Interface, Basis Data. 
d. Implementasi

Implementasi sistem dilakukan berdasarkan perancangan aplikasi. Implementasi perangkat lunak mengimplementasikan analisa kebutuhan perangkat sebagai penunjang untuk membangun sistem, meliputi kebutuhan software berupa bahasa pemrograman Java, PHP dan basis data MySQL serta tools pendukung lainnya sehingga dapat mengimplementasikan kebutuhan-kebutuhan tersebut. Proses perancangan yang dapat dihasilkan adalah sebagai berikut :

1. Implementasi QR Code reader pada android dengan menggunakan bahasa pemrograman Java.

2. Implementasi admin berupa halaman atau tampilan web dengan mengimplemeasikan bahasa pemrograman PHP.

3. Data logistik dimasukkan ke dalam basis data dengan mengimplementasikan basis data MySQL, sehingga data yang tersimpan dalam basis data tersebut akan diolah oleh sistem untuk kebutuhan proses stock opname.

\section{Pengujian Program}

Tahapan akhir dimana sistem yang baru diuji kemampuan dan keefektifannya sehingga didapatkan kekurangan dan kelemahan sistem yang kemudian dilakukan pengkajian ulang dan perbaikan terhadap aplikasi menjadi lebih baik dan sempurna.

Pengujian sistem dilakukan dengan menggunakan metode BlackBox Testing. BlackBox Testing memberikan hasil tes kesesuaian aplikasi dengan fungsi atau kemampuan sistem secara fungsional. BlackBox Testing yaitu pengujian yang difokuskan terhadap fungsionalitas perangkat lunak tanpa melihat struktur internal program. Sehingga dimungkinkan pembuat program atau petugas penguji mendapatkan serangkaian kondisi input yang sepenuhnya menggunakan semua persyaratan fungsional untuk suatu program.

BlackBox Testing berusaha menemukan kesalahan yang termasuk kategori dibawah ini :

1. Fungsi-fungsi yang hilang atau tidak benar.

2. Kesalahan pada design interface.

3. Kesalahan pada performance.

4. Kesalahan pada inisialisasi dan terminasi.

\subsection{Bahan dan Alat Penelitian}

Dalam penelitian ini penulis menggunakan bahan dan peralatan sebagai berikut;

a. Sistem Operasi Windows 8.1

b. Eclipse Standard 4.3.1

c. Sublime Text 3.0

d. PHP (Hypertext Preprocessor)

e. XAMPP sebagai web server.

f. MySQL sebagai DBMS untuk database

g. Browser Chrome

h. Android SDK i. Java Development Kit (JDK)

j. Android Development Tool (ADT)

k. Genymotion

1. Komputer/Laptop.

m. Smartphone Sistem Operasi Android versi 4.0 keatas

\section{Hasil}

Cara kerja untuk mendapatkan data hasil stock opname yaitu dengan menggunakan decoder (pembaca $Q R$ Code) berupa perangkat mobile berbasis android. Setiap barang yang sudah diberikan tanda $Q R$ Code kemudian di scan satu persatu.

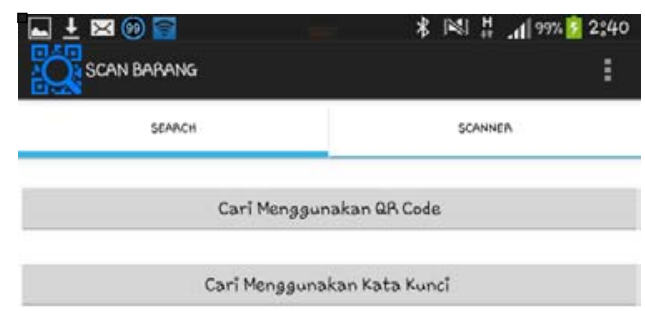

Gambar 3.1 Halaman Pencarian Android

Tampilan android ini terdiri dari 2 bagian, yaitu search dan scanner. Pada halaman search akan disediakan 2 pilihan pencarian, yaitu cari menggunakan QR Code dan cari menggunakan kata kunci. Hal ini ditujukan untuk lebih mempermudah user dalam pencarian barang yang diinginkan.

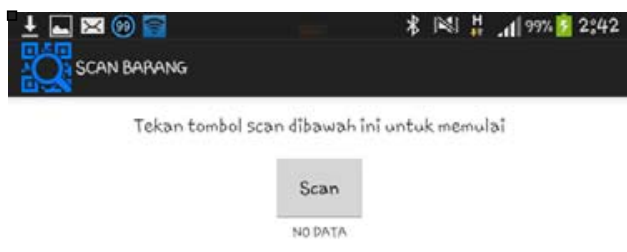

Gambar 3.2 Tampilan Awal Pencarian Menggunakan QR Code QR Code

Tampilan saat memilih menu cari menggunakan 


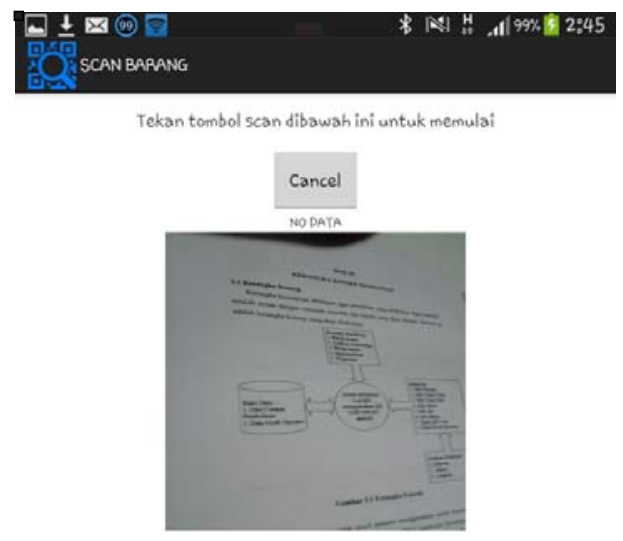

Gambar 3.3 Kamera Aktif Saat Menekan Tombol Scan

Fitur kamera aktif saat memilih tombol scan. Gambar $Q R$ Code pada setiap barang siap di scan untuk mengetahui kode barang yang tersimpan didalamnya untuk mengetahui detail barang tersebut.

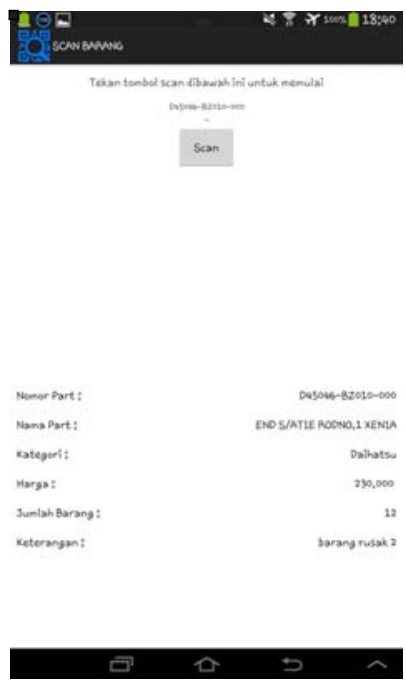

Gambar 3.4 Hasil Search Barang

Fitur kamera yang aktif pada gambar 3.3 akan otomatis menutup sendiri ketika berhasil scan nomor part yang terdapat dalam gambar QR Code. Hasilnya, detail barang yaitu nomor part, nama part, kategori, harga, jumlah barang, dan keterangan dapat diketahui.

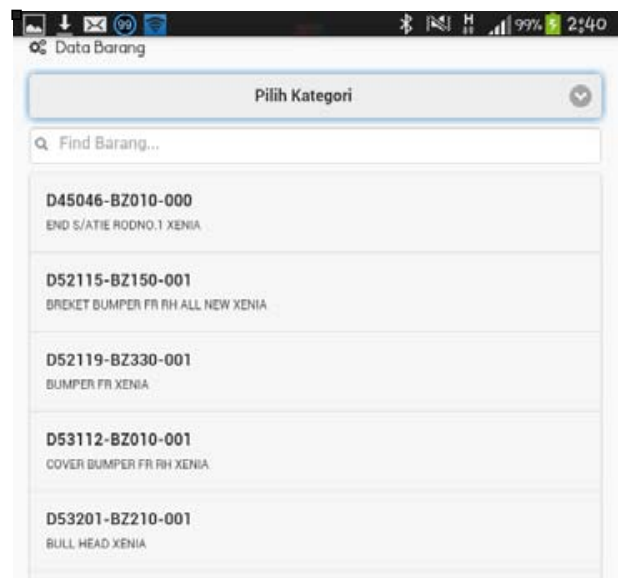

Gambar 3.5 Tampilan Pencarian Barang Menggunakan Kata Kunci

Halaman ini menampilkan seluruh data barang yang ada di database server. Pada gambar 3.5 terdapat pilihan menu pilih kategori untuk mempermudah dalam menyeleksi pencarian barang dan masukkan kata kunci pada kolom yang telah disediakan.

Gambar 3.6 dibawah ini adalah tampilan detail barang setelah mendapatkan barang yang sudah di cari. Detail barang tidak otomatis keluar seperti pada pencarian menggunakan QR Code. User harus memilih terlebih dahulu pada data barang yang telah berhasil dicari sebelumnya.

\begin{tabular}{ll}
\hline Nomor Part & : D45046-BZ010-000 \\
Nama Part & $:$ END S/ATIE RODNO.1 XENIA \\
Kategori & $:$ Daihatsu \\
Quantity & $: 12$ \\
Harga & $:$ RP 230.000 \\
Keterangan & $:$ barang rusak 2
\end{tabular}

Gambar 3.6 Tampilan Detail Barang

Pada halaman scanner, halaman ini hampir sama dengan halaman pencarian menggunakan QR Code, yang membedakan adalah adanya proses lebih lanjut yaitu stock opname.

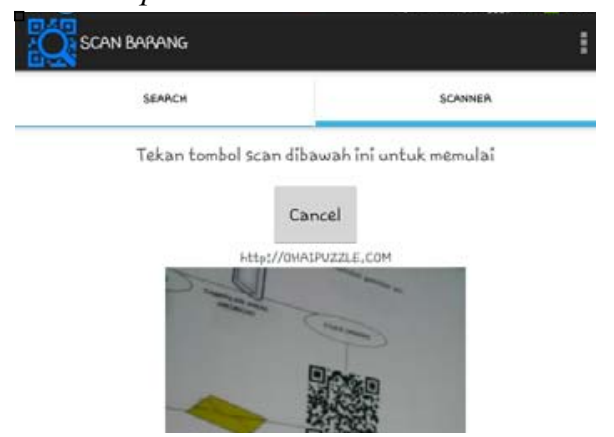

Gambar 3.7 Tampilan Sebelum Melakukan Scan Barang 
Setelah nomor part berhasil didapatkan dari scan gambar QR Code, detail barang akan muncul kecuali jumlah barang (qty) dan keterangan. Jumlah barang dan keterangan harus kita inputkan sendiri untuk membuat data record baru yaitu stock opname. Proses ini akan terus terulang (scan barang) hingga semua barang di gudang berhasil di scan.

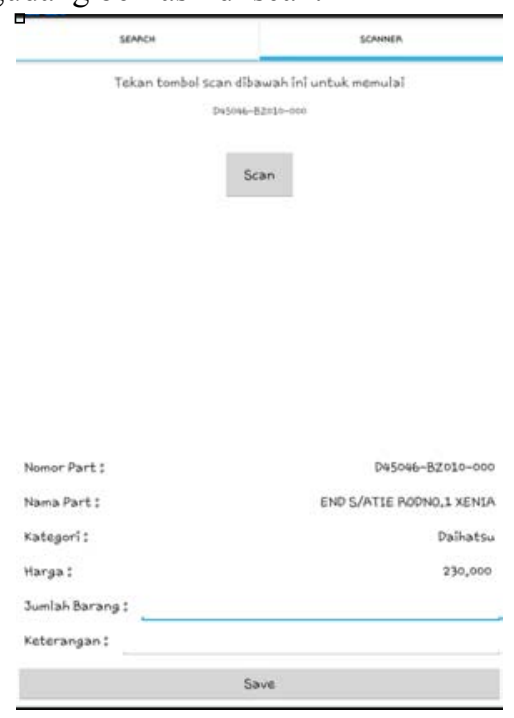

Gambar 3.8 Halaman Proses Stock Opname

\section{Pembahasan}

\subsection{Pengujian}

Pengujian perlu dilakukan apakah aplikasi ini berjalan sesuai dengan ketentuan dan keinginan atau tidak maka harus dilakukan pengujian secara fungsional. Pengujian pada aplikasi ini meliputi dua jenis pengujian, yaitu pengujian fungsional dan pengujian QR Code.

Pengujian sistem dilakukan dengan menggunakan metode BlackBox Testing. BlackBox Testing memberikan hasil tes kesesuaian aplikasi dengan fungsi atau kemampuan sistem secara fungsional untuk mengetahui apakah fitur-fitur dari aplikasi ini berjalan dengan semestinya atau tidak. Dengan mencoba segala kemungkinan yang terjadi, maka kita bisa mengetahui fitur mana sajakah yang perlu diperbaiki.

Pengujian yang kedua adalah pengujian QR Code. Pengujian ini bertujuan untuk mengetahui sejauh mana perangkat android dapat membaca gambar QR Code.
Tabel 4.1 Pengujian Fungsional Scanner Android

\begin{tabular}{|c|c|c|}
\hline Proses & Hasil & Keterangan \\
\hline $\begin{array}{c}\text { Scan gambar } Q R \\
\text { Code dengan nomor } \\
\text { part sesuai dengan } \\
\text { database }\end{array}$ & $\begin{array}{c}\text { Keluar nomor } \\
\text { part, detail } \\
\text { barang, } \\
\text { tombol save, } \\
\text { dan masukkan } \\
\text { qty }\end{array}$ & Sesuai \\
\hline $\begin{array}{c}\text { Scan gambar } Q R \\
\text { Code dengan nomor } \\
\text { part tidak sesuai } \\
\text { dengan database }\end{array}$ & $\begin{array}{c}\text { Hanya keluar } \\
\text { nomor part }\end{array}$ & Sesuai \\
\hline $\begin{array}{c}\text { Pencarian dengan } \\
\text { scan gambar } Q R \\
\text { Code dengan nomor } \\
\text { part sesuai dengan } \\
\text { database tetapi tidak } \\
\text { terhubung dengan } \\
\text { internet }\end{array}$ & $\begin{array}{c}\text { Keluar nomor } \\
\text { part tetapi } \\
\text { tidak dengan } \\
\text { detail barang } \\
\text { dan tombol }\end{array}$ & \\
save & Sesuai \\
\hline $\begin{array}{c}\text { Pencarian dengan } \\
\text { scan gambar } Q R \\
\text { Code tetapi kamera } \\
\text { tidak aktif }\end{array}$ & Tidak bisa & Sesuai \\
& & \\
\hline
\end{tabular}

Tabel 4.2 Pengujian ukuran, jarak dan tingkat kecahayaan

\begin{tabular}{|c|c|c|}
\hline Kondisi QR Code & $\begin{array}{c}\text { QR Code } \\
\mathbf{3 x 3} \mathbf{~ c m}\end{array}$ & $\begin{array}{c}\text { QR Code } \\
\mathbf{6 x 6} \mathbf{~ c m}\end{array}$ \\
\hline Normal (jarak $\pm 10 \mathrm{~cm})$ & Diterima & Diterima \\
\hline Jarak menengah $( \pm 35 \mathrm{~cm})$ & Diterima & Diterima \\
\hline $\begin{array}{c}\text { Jarak menengah }( \pm 35 \mathrm{~cm}) \\
\text { Cahaya minim }\end{array}$ & Ditolak & Diterima \\
\hline Jarak maksimal $( \pm 70 \mathrm{~cm})$ & Ditolak & Diterima \\
\hline $\begin{array}{c}\text { Jarak maksimal }( \pm 70 \mathrm{~cm}) \\
\text { Cahaya minim }\end{array}$ & Ditolak & Ditolak \\
\hline
\end{tabular}

Tabel 4.3 Pengujian ukuran, jarak dan tingkat kecahayaan

\begin{tabular}{|l|l|}
\hline \multicolumn{1}{|c|}{ Deskripsi } & Keterangan \\
\hline $\begin{array}{l}\text { Menguji pembacaan dengan } Q R \text { Code yang } \\
\text { kotor sebagian kecil pada bagian pojok bawah }\end{array}$ & Diterima \\
\hline $\begin{array}{l}\text { Menguji pembacaan dengan } Q R \text { Code yang } \\
\text { kotor sebagian kecil secara vertikal }\end{array}$ & Diterima \\
\hline $\begin{array}{l}\text { Menguji pembacaan dengan } Q R \text { Code yang } \\
\text { kotor sebagian kecil secara horizontal }\end{array}$ & Diterima \\
\hline $\begin{array}{l}\text { Menguji pembacaan dengan } Q R \text { Code yang } \\
\text { kotor sebagian kecil pada bagian pojok atas }\end{array}$ & Diterima \\
\hline $\begin{array}{l}\text { Menguji pembacaan dengan } Q R \text { Code yang } \\
\text { kotor sebagian }\end{array}$ & Ditolak \\
\hline $\begin{array}{l}\text { Menguji pembacaan dengan } Q R \text { Code yang } \\
\text { kotor sebagian besar }\end{array}$ & Ditolak \\
\hline $\begin{array}{l}\text { Menguji pembacaan dengan } Q R \text { Code yang } \\
\text { kotor di 1 bagian finder pattern }\end{array}$ & Ditolak \\
\hline
\end{tabular}




\begin{tabular}{|l|l|}
\hline $\begin{array}{l}\text { Menguji pembacaan dengan } Q R \text { Code yang } \\
\text { kotor di } 2 \text { bagian finder pattern }\end{array}$ & Ditolak \\
\hline $\begin{array}{l}\text { Menguji pembacaan dengan } Q R \text { Code yang } \\
\text { rusak sebagian kecil }\end{array}$ & Diterima \\
\hline $\begin{array}{l}\text { Menguji pembacaan dengan } Q R \text { Code yang } \\
\text { rusak sebagian }\end{array}$ & Diterima \\
\hline $\begin{array}{l}\text { Menguji pembacaan dengan } Q R \text { Code yang } \\
\text { rusak sebagian besar }\end{array}$ & Ditolak \\
\hline $\begin{array}{l}\text { Menguji pembacaan dari } Q R \text { Code dengan } \\
\text { arah terbalik }\end{array}$ & Diterima \\
\hline
\end{tabular}

\subsection{Analisa}

Perlu diperhatikan bahwa perangkat lunak atau aplikasi yang dibangun ini tidak mempengaruhi kinerja dari sistem pada smartphone yang digunakan dan tidak membebani RAM. Aplikasi ini membutuhkan kamera untuk melakukan pembacaan QR Code, karena itu smartphone yang digunakan untuk memasang aplikasi ini harus terdapat kamera. Kamera yang digunakan untuk melakukan pembacaan sebaiknya memiliki resolusi minimal 3,2 megapiksel karena kualitas gambar akan mempengaruhi kinerja pembacaan yang dilakukan oleh aplikasi scanner QR Code.

Berdasarkan pengujian QR Code yang dilakukan diatas, aplikasi scanner reader yang ada pada sistem ini dibangun cukup handal dan dapat membaca QR Code dengan berbagai kondisi. Kondisi-kondisi yang telah diuji untuk membuktikan kehandalan aplikasi scanner reader adalah kondisi QR Code rusak, kotor, tidak dalam posisi yang benar, jarak, ukuran, hingga kepada pencahayaan.

Namun, toleransi terhadap kerusakan dan kotor pada gambar QR Code yang dibaca terbatas. Pada pengeksekusiannya tidak selalu didapat hasil yang optimal. Berikut adalah contoh kegagalan yang terjadi pada saat pengujian $Q R$ Code dengan kondisi normal jarak $\pm 10 \mathrm{~cm}$.

Dari beberapa analisis faktor kegagalan dalam pengujian diatas, maka didapatkan beberapa factor kegagalan tersebut, antara lain:

a. Pencahayaan yang terlalu gelap ataupun terlalu terang sehingga membuat QR Code tidak terlihat sepenuhnya.

b. Kondisi QR Code yang kurang baik, seperti warnanya sudah pudar atau kertas tempat QR Code berada dalam kondisi yang jelek.

c. Terdapat berbagai macam benda yang dapat menutupi QR Code lebih dari 30\%, sehingga mengakibatkan data pada $\mathrm{QR}$ Code tidak dapat terbaca. d. Semakin jauh pengambilan jarak akan sangat mempengaruhi dalam pembacaan QR Code.

\section{Penutup}

\subsection{Kesimpulan}

Berdasarkan implementasi, pengujian, dan analisis yang telah dilakukan, ada beberapa kesimpulan yang dapat diambil. Kesimpulankesimpulan tersebut adalah sebagai berikut :

a. Sistem informasi logistik dapat diterapkan secara mobile dengan menampilkan daftar data barang, detail data barang, dan fitur pencarian baik itu melalui QR Code atau kata kunci.

b. QR Code dapat dimanfaatkan sebagai alat identifikasi dalam sebuah sistem informasi logistik stock opname menggunakan perangkat mobile berbasis android, karena QR Code dapat menyimpan informasi yang cukup, dalam hal ini adalah untuk nomor part.

c. Smartphone Android dapat dimanfaatkan dan diintegrasikan untuk membaca QR Code dengan menggunakan sistem informasi logistik stock opname tanpa membebani kinerja dari smartphone tersebut. Meskipun mengambil data dari server.

d. Semua data barang dan hasil stock opname dapat ditampilkan dan di olah melalui halaman web untuk admin.

e. Sistem informasi logistik stock opname yang telah dibangun terbukti cukup handal dalam melakukan pembacaan QR Code baik itu QR Code yang rusak, kotor, ataupun terbalik posisinya.

\subsection{Saran}

Penelitian ini masih dapat dikembangkan dan disempurnakan, berikut merupakan beberapa hal yang disarankan untuk pengembangan aplikasi ini, yaitu:

a. Penggunaan QR Code bisa lebih dimanfaatkan dalam hal barang masuk maupun barang keluar yang terjadi menggunakan android.

b. Fitur cetak laporan berdasarkan tanggal tertentu atau rentang waktu tertentu yang dapat di inputkan user atau admin sesuai ke hendaknya.

\section{Daftar Pustaka:}

Gargenta, M. 2011. Learning Android. O'Reilly Media: California.

Hashimi, Sayed Y., Komatineni, Satya. 2009. Pro Android. Apress: New York. 
Ariadi. 2011. Analisis dan Perancangan Kode Matriks Dua Dimensi Quick Response (QR) Code. Skripsi : Universitas Sumatera Utara.

Prasetyo, R. Muhammad Khalil. 2012 Penyelesaian Permainan Checkers Pada Mobile Device Berbasis Android Menggunakan Algoritma Iterative Deepening Search. Skripsi : Universitas Sumatera Utara.

Kato, Hiroko,dkk. 2010. Barcodes for Mobile Devices.New York : Cambridge University Press.

Soon, Tan Jin. 2008. Systhesis Journal 2008 section three: hal 59-68

Yeni, Dwi Rahayu. 2009. Pembuatan Aplikasi Pembacaan Quick Response Code Menggunakan Perangkat Mobile Berbasis J2ME Untuk Identifikasi Suatu Barang : Surabaya

Huda, Arif Akbarul. 2012. 24 Jam Pintar Pemrograman Android. Yogyakarta : Andi

Lukmana, Lukas. 2012. Membuat Aplikasi Android Untuk Tablet dan Handphone. Jakarta : Gramedia.

Tim EMS. 2013. Android All In One. Jakarta : Gramedia 